\title{
REVIEW ON AFLATOXIN IN INDONESIAN FOOD- AND FEEDSTUFFS AND THEIR PRODUCTS
}

\author{
OKKY SETYAWATI DHARMAPUTRA
}

SEAMEO BIOTROP, P.O. Box 116, Bogor, Indonesia; and

Department of Biology , Faculty of Mathematics and Natural Sciences,

Bogor Agricultural University, Jl. Raya Pajajaran, Bogor, Indonesia

\begin{abstract}
Aflatoxin is a human carcinogen that could contaminate food- and feedstuffs, and hence is a major food quality problem throughout the world. Afiatoxin is produced by certain strains of AspergillusJlavus and //. parasiticus. A number of studies have been carried out in Indonesia on atlatoxin contamination in Indonesian food- and feedstuffs and their products from 1990 up to present. They were maize, maize product, peanuts, soybean and soybean meal, black and white pepper, feed ingredients; chicken and duck feeds. Samples were collected from farmers, traders (middlemen), retailers (markets), supermarkets, exporters; poultry and duck community-based farms; and feed mill industries. High levels of aflatoxins were often found in maize, peanuts, chicken feed derived from markets, and duck feed. Low levels of aflatoxins were found in soybean meal and chicken feedstuff. Aflatoxins were not detected in soybean, black and white pepper.

Other studies have also been carried out on the effect of carbondioxide (CO2), phosphine, black pepper extract and antagonistic fungi on aflatoxin production of A. flavus in vitrol and the effect of airtight storage, phosphine, ammonium hydroxide, fermentation process, bag types, and phosphine in combination with different bag types on atlatoxin contents of maize, peanuts and soybean meal. Some of these methods reduced aflatoxin contents significantly.
\end{abstract}

Keywords: Aspergillus flavus I Aflatoxin / Food-and feed stuffs / Product

\section{INTRODUCTION}

Aflatoxin is a human carcinogen that contaminates food-and feedstuffs, produced by the common fungi Aspergillus flavus and A. parasiticus. The aflatoxin problem is a worldwide phenomenon, but it is particularly severe in developing countries, where food safety and security systems are not well developed to protect consumers against unsafe food products. In more developed countries, consumers are more aware of food safety issues such as aflatoxin, and are increasingly demanding those foods meet strict regulatory standards.

Aflatoxin limits for some commodities by importing countries are presented in Table 1. Among the foodstuff, peanuts is easily contaminated with aflatoxin. Based on the report of the $23^{\text {rd }}$ Session of the Joint FAp/WHO Food Standards Programme, held in Rome, Italy, 28 June - 3 July 1999, Codex Alimentarius Commission adopted the maximum level of total aflatoxins in peanuts intended for further processing at $15 \mathrm{ppb}$. 
This paper reviews the researches that have been undertaken in Indonesia from 1990 to date on aflatoxin contamination in food- and feedstuffs and their products, as well as control ofA.flavus and aflatoxin.

Table 1. Aflatoxin limits (ppb) for some commodities by importing, countries (Lubulwa and Davis 1994).

\begin{tabular}{|c|c|c|c|c|c|c|}
\hline Country & Aflatoxins & Peanuts & $\begin{array}{l}\text { Nut, } \\
\text { cereals }\end{array}$ & $\begin{array}{l}\text { Maize } \\
\text { and } \\
\text { maize } \\
\text { products }\end{array}$ & $\begin{array}{l}\text { Feeds for } \\
\text { dairy and } \\
\text { young } \\
\text { cattle and } \\
\text { pigs }\end{array}$ & $\begin{array}{c}\text { Feedstuffs } \\
\text { for pigs } \\
\text { and } \\
\text { poultry }\end{array}$ \\
\hline USA & $\mathrm{B}_{1}+\mathrm{B}_{2}+\mathrm{G}_{1}+\mathrm{G}_{2}$ & 20 & 20 & 20 & 20 & 20 \\
\hline Japan & $\mathrm{B}_{1}$ & 10 & 10 & 10 & 10 & 20 \\
\hline $\begin{array}{l}\text { European } \\
\text { Community }\end{array}$ & $\mathrm{B}_{1}+\mathrm{B}_{2}+\mathrm{G}_{1}+\mathrm{G}_{2}$ & 5 to 50 & 1 to 30 & 5 to 50 & 10 & 20 \\
\hline France & $\mathrm{B}_{1}+\mathrm{B}_{2}+\mathrm{G}_{1}+\mathrm{G}_{2}$ & $\begin{array}{l}0.1 \text { (nut } \\
\text { pastes) }\end{array}$ & 5 & 10 & 5 & 10 \\
\hline Germany & $\mathrm{B}_{1}$ & 5 & 2 & & 5 & 10 \\
\hline Netherlands & $\mathrm{B}_{1}$ & 50 & & & 5 & 10 \\
\hline Britain & $\mathrm{B}_{1}+\mathrm{B}_{2}+\mathrm{G}_{1}+\mathrm{G}_{2}$ & 10 & 10 & 10 & & \\
\hline
\end{tabular}

\section{AFLATOXIN IN FOOD-AND FEEDSTUFFS AND'THEIR PRODUCTS}

\section{Aflatoxin in maize and maize products}

In Indonesia, maize is the second most important crop after rice. Purwoko et al. (1991) studied aflatoxin content of 34 maize samples collected from poultry farms and poultry feedmills located around Jakarta and Bogor. Aflatoxins were found in $91 \%$ of maize samples, and the predominant form was aflatoxin $\mathrm{B} \mid$. The total concentration of aflatoxins in maize samples ranged from 22 to $6171 \mathrm{ppb}$, of which 91\% contained aflatoxin $\mathrm{B}_{\mathrm{h}}$ ranging from 22 to $4074 \mathrm{ppb}$, while aflatoxin $\mathrm{B}_{2}(71 \%)$ ranged from 11 to $3021 \mathrm{ppb}$. Aflatoxin G, was present in two samples, at concentration of 101 and $528 \mathrm{ppb}$, and only one sample contained aflatoxin $\mathrm{G}_{2}$ at concentration of $144 \mathrm{ppb}$.

Maryam (1994) studied aflatoxin contamination of 32 maize samples derived from diagnostic samples sent to the Research Institute for Veterinary Science, 
Bogor. It was reported that the percentage of maize samples contaminated with aflatoxin $B, B_{2}, G$, and $G_{2}$ were 78.1, 78.1, 20.0 and $20.0 \%$, respectively. Their ranges were between 1.1 - 63.7, 0.5 - 12.6, 1.2 - 51.7, and 0.6 - 4.2 ppb, respectively (Table 2).

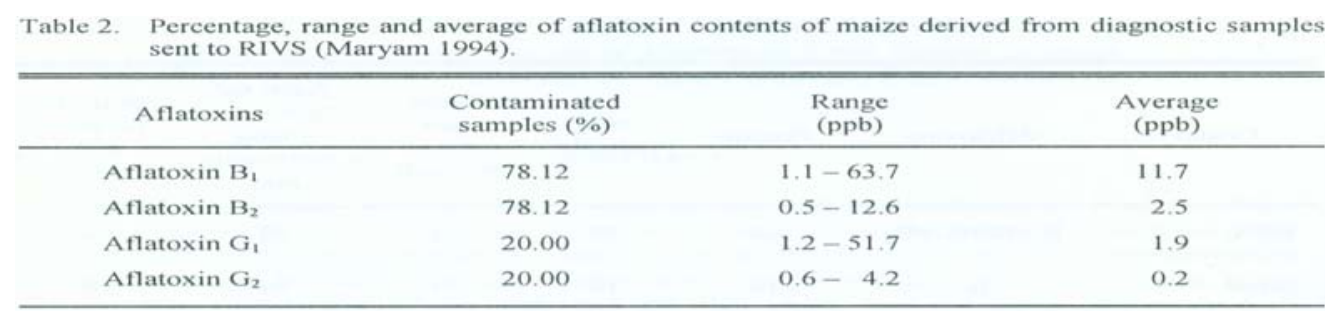

A study by Dharmaputra et al. (1995) on aflatoxin content of 35 maize samples collected from farmers and traders in Lampung province in November 1992 reported that all of the samples (100\%) contained aflatoxin BI, and 31\% contained aflatoxin $\mathrm{B}_{2}$ (Table 3). Eleven samples obtained from farmers contained 25.4 - $367 \mathrm{ppb}$ of aflatoxin $\mathrm{B}_{\mathrm{h}}$ and 2 samples contained 12.5 and $12.7 \mathrm{ppb}$ of aflatoxin $\mathrm{B}_{2}$, respectively; 4 samples obtained from village traders contained 119.7 - $276.7 \mathrm{ppb}$ of aflatoxin $\mathrm{B}$ ! and $11.9-41.6 \mathrm{ppb}$ of aflatoxin $\mathrm{B}_{2}, 4$ samples obtained from middle traders contained only aflatoxin B! (25.6 - $97.6 \mathrm{ppb}) ; 16$ samples of big traders contained $23.4-278.7 \mathrm{ppb}$ of aflatoxin B, and 5 samples contained $24.2-61.2 \mathrm{ppb}$ of aflatoxin $\mathrm{B}_{2}$.

Table 1. Aflatoxin limits (ppb) for some commodities by importing, countries (Lubulwa and Davis 1994).

\begin{tabular}{|c|c|c|c|c|c|c|}
\hline Country & Aflatoxins & Peanuts & $\begin{array}{l}\text { Nut, } \\
\text { cereals }\end{array}$ & $\begin{array}{c}\text { Maize } \\
\text { and } \\
\text { maize } \\
\text { products }\end{array}$ & $\begin{array}{l}\text { Feeds for } \\
\text { dairy and } \\
\text { young } \\
\text { cattle and } \\
\text { pigs }\end{array}$ & $\begin{array}{c}\text { Feedstuffs } \\
\text { for pigs } \\
\text { and } \\
\text { poultry }\end{array}$ \\
\hline USA & $\mathrm{B}_{1}+\mathrm{B}_{2}+\mathrm{G}_{1}+\mathrm{G}_{2}$ & 20 & 20 & 20 & 20 & 20 \\
\hline Japan & $\mathrm{B}_{1}$ & 10 & 10 & 10 & 10 & 20 \\
\hline $\begin{array}{l}\text { European } \\
\text { Community }\end{array}$ & $\mathrm{B}_{1}+\mathrm{B}_{2}+\mathrm{G}_{1}+\mathrm{G}_{2}$ & 5 to 50 & 1 to 30 & 5 to 50 & 10 & 20 \\
\hline France & $\mathrm{B}_{1}+\mathrm{B}_{2}+\mathrm{G}_{1}+\mathrm{G}_{2}$ & $\begin{array}{l}0.1 \text { (nut } \\
\text { pastes) }\end{array}$ & 5 & 10 & 5 & 10 \\
\hline Germany & $\mathrm{B}_{1}$ & 5 & 2 & & 5 & 10 \\
\hline Netherlands & $B_{1}$ & 50 & & & 5 & 10 \\
\hline Britain & $\mathrm{B}_{1}+\mathrm{B}_{2}+\mathrm{G}_{1}+\mathrm{G}_{2}$ & 10 & 10 & 10 & & \\
\hline
\end{tabular}


BIOTROPIA NO. 19,2002

Table 3. Continued

\begin{tabular}{|c|c|c|c|c|c|c|}
\hline \multirow{2}{*}{$\begin{array}{l}\text { Sample } \\
\text { number }\end{array}$} & \multirow{2}{*}{ Source } & \multirow{2}{*}{$\begin{array}{l}\text { Maize } \\
\text { type }\end{array}$} & \multirow{2}{*}{$\begin{array}{l}\text { No. of } \\
\text { sample }\end{array}$} & \multicolumn{3}{|c|}{ Aflatoxin content (ppb) } \\
\hline & & & & $\mathrm{B}_{1}$ & $\mathrm{~B}_{2}$ & Total $\mathrm{B}_{1}$ \\
\hline 11 & & Cob & & 79.4 & 0 & 79.4 \\
\hline 12 & Village trader & Shelled & 4 & 163.7 & 23.5 & 168.7 \\
\hline 13 & & Shelled & & 194.1 & 24.1 & 199.2 \\
\hline 14 & & Shelled & & 276.7 & 41.6 & 285.6 \\
\hline 15 & & Shelled & & $119.7^{\circ}$ & 11.9 & 112.2 \\
\hline 16 & Middle trader & Shelled & 4 & 97.6 & 0 & 97.6 \\
\hline 17 & & Shelled & & 25.6 & 0 & 25.6 \\
\hline 18 & & Cob & & 27.4 & 0 & 27.4 \\
\hline 19 & & Cob & & 92.2 & 0 & 92.2 \\
\hline 20 & Big trader & Shelled & 16 & 46.8 & 0 & 46.8 \\
\hline 21 & & Shelled & & 46.8 & 0 & 46.8 \\
\hline 22 & & Shelled & & 100.8 & 40.7 & 109.5 \\
\hline 23 & & Shelled & & 45.7 & 0 & 45.7 \\
\hline 24 & & Shelled & & 91.5 & 0 & 91.5 \\
\hline 25 & & Shelled & & 46.4 . & 0 & 46.4 \\
\hline 26 & & Shelled & & 138.9 & 44.8 & 148.4 \\
\hline 27 & & Shelled & & 117.1 & 0 & 117.1 \\
\hline 28 & & Shelled & & 48.1 & 0 & 48.1 \\
\hline 29 & & Shelled & & 167.4 & 24.2 & 172.55 \\
\hline 30 & & Shelled & & 23.4 & 0 & 23.4 \\
\hline 31 & & Shelled & & 278.7 & 61.2 & 291.72 \\
\hline 32 & & Shelled & & 91.2 & 0 & 91.2 \\
\hline 33 & & Shelled & & 140.9 & 0 & 140.9 \\
\hline 34 & & Shelled & & 69.1 & 0 & 69.1 \\
\hline 35 & & Shelled & & $117.2^{\circ}$ & 25.4 & 122.60 \\
\hline
\end{tabular}

Conversion factor $\mathrm{B}_{1}=4.7$

Another study on aflatoxin content of 108 maize samples collected from farmers, and 32 samples from village traders during the dry and wet seasons in Central Lampung (Lampung province) and Kediri (East Java province) regencies was conducted in 1993 - 1994 (Dharmaputra et al. 1996a). At farmers level, the total aflatoxin B| contents was between 5.3 291.4 ppb, while at village trader level, between 9.7 - 115.2 ppb (Table 4). 
Review on Aflatoxin in Indonesia Food-and Feedstuff's and Their Products - Okky S. Dharmaputra

\begin{tabular}{|c|c|c|c|}
\hline \multirow{2}{*}{ Location } & \multirow{2}{*}{ Season } & \multicolumn{2}{|c|}{ Total aflatoxin $\mathrm{B}_{4}(\mathrm{ppb})$} \\
\hline & & Farmer & Trader \\
\hline \multirow[t]{2}{*}{ Central Lampung } & Dry & $5.3-291.4$ & $11.3-104.2$ \\
\hline & Wet & $8.6-153.5$ & $20.6-69.0$ \\
\hline \multirow[t]{2}{*}{ Kediri } & Dry & $31-119.7$ & $9.7-92.5$ \\
\hline & Wet & $11.4-282.7$ & $20.8-115.2$ \\
\hline
\end{tabular}

A study by Dharmaputra and Putri (1996b) on total aflatoxin B, content in 11 samples of maize and maize products collected from some supermarkets in Bogor, West Java, reported that 1 sample of popcorn contained $15 \mathrm{ppb}$ of the toxin; 1 sample of maizena flour contained $20 \mathrm{ppb}$ of the toxin; 2 samples of maize for popcorn contained 40 and $40 \mathrm{ppb}$ of the toxin, respectively; 1 sample of "maize chip" contained 19 ppb of the toxin. Nondetected aflatoxin was observed in 2 samples of popcorn, 1 sample of "marning", 2 samples of maize oil, and 1 sample of tortilla chips (Table 5).

Table 5. Aflatoxin content of maize and maize products collected from some supermarkets in Bogor (Dharmaputra and Putri 1996b).

\begin{tabular}{llr}
\hline \hline Date of sampling & Maize and maize products & Total aflatoxin $\mathrm{B}_{1}$ content (ppb) \\
\hline 4 November 1994 & Popcorn & 15 \\
& Maizena & 20 \\
& Maize for popcorn & 40 \\
& Marning & 0 \\
& Maize oil & 0 \\
& Maize chip & 19 \\
& Tortilla chips & 0 \\
& Maize for popcorn & 40 \\
& Popcorn & 10 \\
& Popcorn & 0 \\
& Maize oil & 0 \\
\hline
\end{tabular}




\section{Aflatoxin in peanuts and peanut products}

Peanuts is next to maize and soybeans as secondary crop of Indonesia. Dharmaputra et al. (1991) reported the aflatoxin contents in 35 peanut samples collected from 15 retailers located in three markets in Bogor, West Java, in September 1988. The aflatoxin contents were between 0 - $1154 \mathrm{ppb}$, while $80 \%$ of the peanut samples contained more than 30 ppb of aflatoxin.

Another study carried out by Haryadi and Setiastuty (1994) on aflatoxin contamination in 30 samples of raw and processed peanuts collected from various traders (big, medium and small) and processors during rainy and dry seasons in and around Bogor (West Java) and Denpasar (Bali), reported that aflatoxin B, was detected in 8 out of 15 samples collected during the rainy season, and in 5 samples collected during the dry season. Aflatoxin $\mathrm{B}_{2}$ was detected in some samples contaminated with aflatoxin BI (Tables 6 and 7). The possibility of aflatoxin contamination was higher among small traders, although big traders cannot guarantee that their products were free from aflatoxin contamination. The study also revealed that in processed peanuts, aflatoxins could still be present.

Table 6. Aflatoxins contents in raw peanuts collected from various traders and processors during wet and dry seasons around Bogor and Denpasar (Haryadi and Setiastuty 1994).

\begin{tabular}{|c|c|c|c|c|c|c|c|c|c|}
\hline \multirow{3}{*}{$\begin{array}{c}\text { Type and scale } \\
\text { of business }\end{array}$} & & \multicolumn{8}{|c|}{ Aflatoxins contents (ppb) } \\
\hline & & \multicolumn{4}{|c|}{ Wet season } & \multicolumn{4}{|c|}{ Dry season } \\
\hline & & $\mathrm{B}_{1}$ & $\mathrm{~B}_{2}$ & $\mathrm{G}_{1}$ & $\mathrm{G}_{2}$ & $\mathrm{~B}_{1}$ & $\mathrm{~B}_{2}$ & $\mathrm{G}_{1}$ & $\mathrm{G}_{2}$ \\
\hline \multirow[t]{2}{*}{ Big traders } & 1 & 2.5 & - & - & - & - & - & - & - \\
\hline & 2 & 10.0 & - & - & - & - & - & - & - \\
\hline \multirow[t]{2}{*}{ Medium traders } & 1 & - & - & - & - & - & - & - & - \\
\hline & 2 & - & - & - & - & - & - & - & - \\
\hline \multirow[t]{4}{*}{ Small traders } & 1 & 5.0 & - & - & - & - & - & - & - \\
\hline & 2 & 2.5 & 20.0 & - & - & 2.5 & - & - & - \\
\hline & 3 & 5.0 & - & - & - & 5.0 & - & - & - \\
\hline & 4 & 30.0 & - & - & - & 5.0 & 25.0 & - & - \\
\hline \multirow[t]{2}{*}{ Processors } & 1 & - & - & - & - & - & - & - & - \\
\hline & 2 & 10.0 & 2.5 & - & - & - & - & - & - \\
\hline
\end{tabular}

$(-)$ : undetected 
Review on Aflatoxin in Indonesia Food-and Feedstuff's and Their Products — Okky S. Dharmaputra

Table 7. Aflatoxins contents in processed peanuts (Haryadi and Setiastuty 1994).

\begin{tabular}{lccccccccc}
\hline \hline \multirow{2}{*}{\begin{tabular}{c} 
Type and scale of $\begin{array}{c}\text { Aflatoxins contents (ppb) } \\
\text { business }\end{array}$ \\
\cline { 2 - 9 }
\end{tabular}} & \multicolumn{8}{c}{ Wet season } \\
\cline { 2 - 9 } & & $\mathrm{B}_{1}$ & $\mathrm{~B}_{2}$ & $\mathrm{G}_{1}$ & $\mathrm{G}_{2}$ & $\mathrm{~B}_{1}$ & $\mathrm{~B}_{2}$ & $\mathrm{G}_{1}$ & $\mathrm{G}_{2}$ \\
\hline Big traders & 1 & - & - & - & - & - & - & - & - \\
& 2 & 15.0 & 5.0 & - & - & 2.5 & - & - & - \\
Small traders & 1 & - & - & - & - & - & - & - & - \\
Processors & 1 & - & - & - & - & - & - & - & - \\
& 2 & - & - & - & - & - & - & - & - \\
\hline
\end{tabular}

$(-)$ : undetected

Dharmaputra et al. (2002) reported that only one out of 15 samples of roasted pod and flour, and 14 samples of coated kernels of peanut collected from supermarkets in Bogor, Malang, Pati and Yogyakarta contained total aflatoxin of 15.54 and 20.72 ppb, respectively.

Table 8 shows the levels of aflatoxin found in maize and peanut samples from retailers located around Bogor and Yogyakarta. Forty five percent of 215 peanut samples contained more than $50 \mathrm{ppb}$ of aflatoxin, 33\% more than $300 \mathrm{ppb}$, and 22\% exceeded $1000 \mathrm{ppb}$ (Pitt and Hocking, 1996). Aflatoxin levels exceeding $300 \mathrm{ppb}$ must be considered unsatisfactory, while those exceeding $1000 \mathrm{ppb}$ must be considered totally unsatisfactory, capable of inducing acute toxic effects in both human and animals. An amount of $1 \%$ of maize and $17 \%$ of peanut samples, contained more than $1000 \mathrm{ppb}$ aflatoxin.

Table 8. The percentage of maize and peanut samples contaminated with different levels of total aflatoxin content (Pitt and Hocking 1996).

\begin{tabular}{lrc}
\hline \hline \multicolumn{1}{c}{$\begin{array}{c}\text { Total aflatoxin content } \\
\text { (range) }(\mathrm{ppb})\end{array}$} & Maize (\%) & Peanuts (\%) \\
\hline$\geq 5$ & 68 & 44 \\
$>5 \leq 10$ & 2 & 1 \\
$>10 \leq 50$ & 8 & 10 \\
$>50 \leq 300$ & 18 & 12 \\
$>300 \leq 1000$ & 3 & 11 \\
$>1000 \leq 5000$ & 1 & 5 \\
$>5000$ & 0 & 215 \\
Total no. of samples & 96 & 920 \\
Total production (t, 1991) & 6409 & \\
\hline
\end{tabular}




\section{Aflatoxin in soybean and soybean meal}

In Indonesia, soybean ranks next to maize in importance as secondary food crops. The protein content of soybean is relatively high (42 - 50\%), thus soybean meal is an important component of feedstuff. Purwoko et at. (1991) studied aflatoxin contents of 10 soybean samples collected from some poultry farms and poultry feed mills located around Jakarta and Bogor in July 1990. Aflatoxins were not detected in the samples.

Dharmaputra et al. (1997) reported that only 5 soybean meal samples were contaminated by aflatoxin from a study on aflatoxin content of 13 soybean meal samples collected from 10 feed mills factories, three BULOG warehouses and one soybean crushing plant factory. The contents of aflatoxin were 7.9, 11.3, 14.5, 28.5 and 34 ppb, respectively. According to Venkitasubramanian (1977), phytic acid in soybeans can bind zinc ions, while zinc ions are the important elements of aflatoxin synthesis.

\section{Aflatoxin in pepper}

Among spices, black and white pepper are important export commodities in Indonesia. Aflatoxins were not detected in 40 samples of black and white pepper (20 samples/commodity) collected from some retailers and supermarkets in Bogor, and some exporters in Bangka island and Lampung province (Dharmaputra et al. 1999).

\section{Aflatoxin in chicken feed, duck feed, mixed duck feed, and rice bran}

Dharmaputra and Putri (1996b) reported that the total aflatoxin B[ content of 39 chicken feed samples collected from 3 markets in Bogor during dry and wet seasons was between 0 - $200.73 \mathrm{ppb}$. Twenty six out of 39 samples (67\%) contained aflatoxins more than $30 \mathrm{ppb}$.

A study by Zahari and Tarmudji (1995) on the aflatoxin content of 19 duck feed, 8 mixed duck feed and 8 rice bran samples collected from a duck farm in South Kalimantan reported that in duck feed 100, 100, 52.6 and $15.8 \%$ of the samples were contaminated with aflatoxins $B_{\text {: }} B_{2}, G$, and $G_{2}$, respectively. Their contents were between 4.0 - 160.0 ppb, 4.8 $60.0 \mathrm{ppb}, 0$ - $60.0 \mathrm{ppb}$, and 0 - $8.0 \mathrm{ppb}$, respectively. In mixed duck feed, only one sample was contaminated with aflatoxin B,, and its content was $8.0 \mathrm{ppb}$. In rice bran, $75 \%$ of the samples were contaminated with aflatoxin B|. Their contents were between $0-20.0 \mathrm{ppb}$. Two out of 8 samples (25\%) contained 7.2 and 72.0 of aflatoxin $\mathrm{B}_{2}$. Only one sample of rice bran was contaminated with aflatoxin $\mathrm{G}$, (3.2 ppb). No aflatoxin $\mathrm{G}_{2}$ was detected in all samples. 


\section{CONTROL OF ASPERGILLUS FLA VUS AND AFLATOXIN}

\section{The effects of carbondioxide on mycelial growth and aflatoxin production of A. flavus in pure culture}

Dharmaputra et al. (1992) studied the effects of $\mathrm{CO}_{2}$ concentrations of 20, 40, 60 and 80\% on mycelial growth and aflatoxin production of three isolates of A. flavus. As a control, these fungal isolates were maintained in air. The $\mathrm{CO}_{2}$ concentrations used significantly affected both mycelial growth and aflatoxin production of $A$. flavus isolates. $\mathrm{CO}_{2}$ at $20 \%$ started to inhibit the two parameters (Figures 1 and 2). The growth of A. flavus and aflatoxin production decreased with the increase of $\mathrm{CO}_{2}$ concentrations.

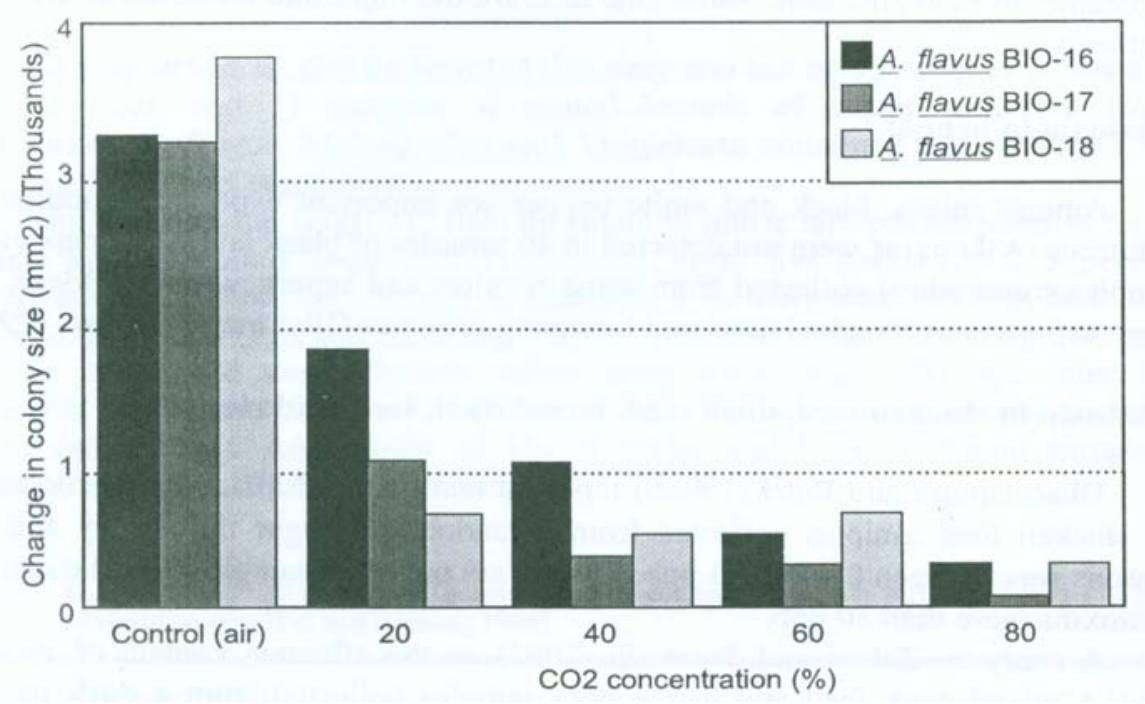

Figure 1. Mycelial growth of A. flavus BIO-16, BIO-17 and BIO-18 after treatment with different concentrations of $\mathrm{CO}_{2}$ for 7 x 24 h on Potato Dextrose Agar (Dharmaputra et al. 1992). 


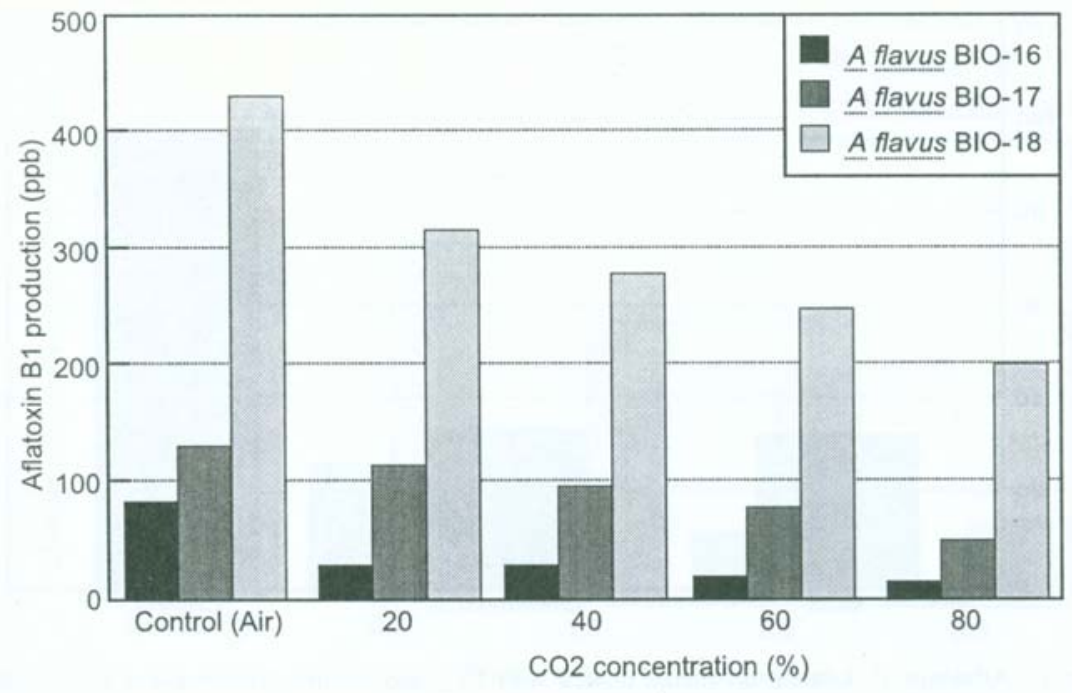

Figure 2. Aflatoxin $\mathrm{B}_{1}$ production of A. flavus $\mathrm{BIO}-16, \mathrm{BIO}-17$ and $\mathrm{BIO}-18$ after treatment with different concentrations of $\mathrm{CO}_{2}$ for $10 \times 24 \mathrm{~h}$ on Coconut Extract Medium 10\% (Dharmaputra et al. 1992).

\section{The effect of carbondioxide on aflatoxin production in maize}

An investigation was carried out by Dharmaputra et al. (1990) on the effect of $\mathrm{CO}_{2}$ on aflatoxin production in stored maize. Stacks of stored maize were sealed with PVC sheeting and treated with $\mathrm{CO}_{2}$ for storage periods varying from 10 to 120 days. The concentration of $\mathrm{CO}_{2}$ used was $2.4 \mathrm{~kg} / \mathrm{t}$. The control groups consisted of both stacks of maize sealed in plastic sheets, but not treated with $\mathrm{CO}_{2}$, and stacks not sealed in plastic sheets.

The aflatoxin $\mathrm{B}$, content of maize, whether in plastic sheets and treated with $\mathrm{CO}_{2}$ or only in plastic sheets, was lower than that of the unsheeted and untreated stacks (Figure 3). The control showed that the aflatoxin content increased with the increasing duration of storage. 


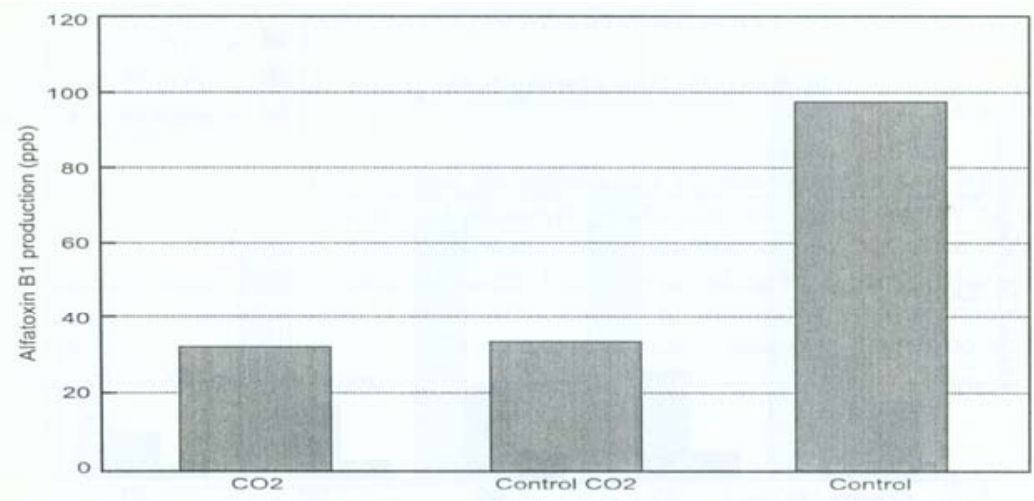

Figure 3. Aflatoxin $\mathrm{B}_{1}$ content on maize treated with $\mathrm{CO}_{2}$ and control (Dharmaputra et al. 1990). Control $\mathrm{CO}_{2}$ : stacks of maize enclosed in PVC plastic, but not treated with $\mathrm{CO}_{2}$ Control : stacks not enclosed in PVC plastic.

The effect of phosphine on mycelial growth and aflatoxin production of $A$. flavus in pure culture

Dharmaputra et al. (1991) studied the effect of phosphine on mycelial growth and aflatoxin B, production of two A. flavus isolates. The concentrations of phosphine used were $0.5,1.5,2.5$ and $3.5 \mathrm{mg} / \mathrm{L}$. As a control, these fungal isolates were maintained in air.

The phosphine concentrations significantly affected both the mycelial growth and aflatoxin production of the isolates of A. flavus. Mycelial growth and aflatoxin production decreased with increasing phosphine concentrations (Figures 4 and 5). Inhibition of mycelial growth commenced at $0.5 \mathrm{mg} / \mathrm{L}$ (Figure 4). Although the two isolates were still able to produce aflatoxin after treatment with $3.5 \mathrm{mg} / \mathrm{L}$ of phosphine, the amounts were low (Figure 5). 


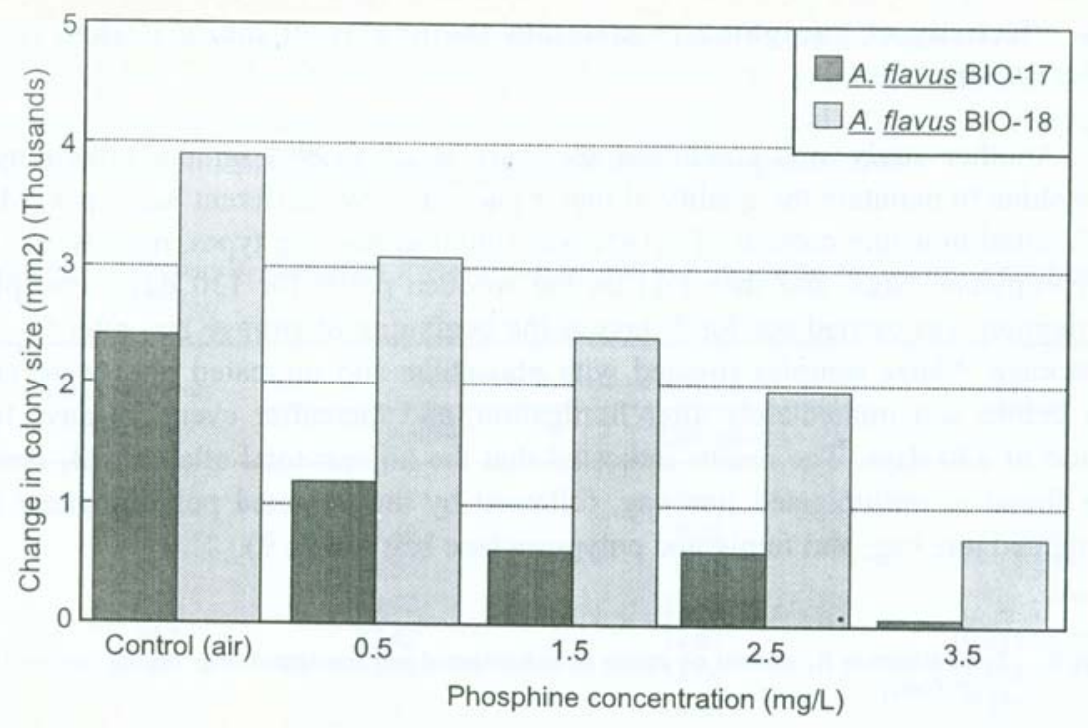

Figure 4. Mycelial growth of A. flavus BIO-16, BIO-17 and BIO-18 after treatment with different concentrations of phosphine for 5 x 24h on Potato Dextrose Agar (Dharmaputra et al. 1991).

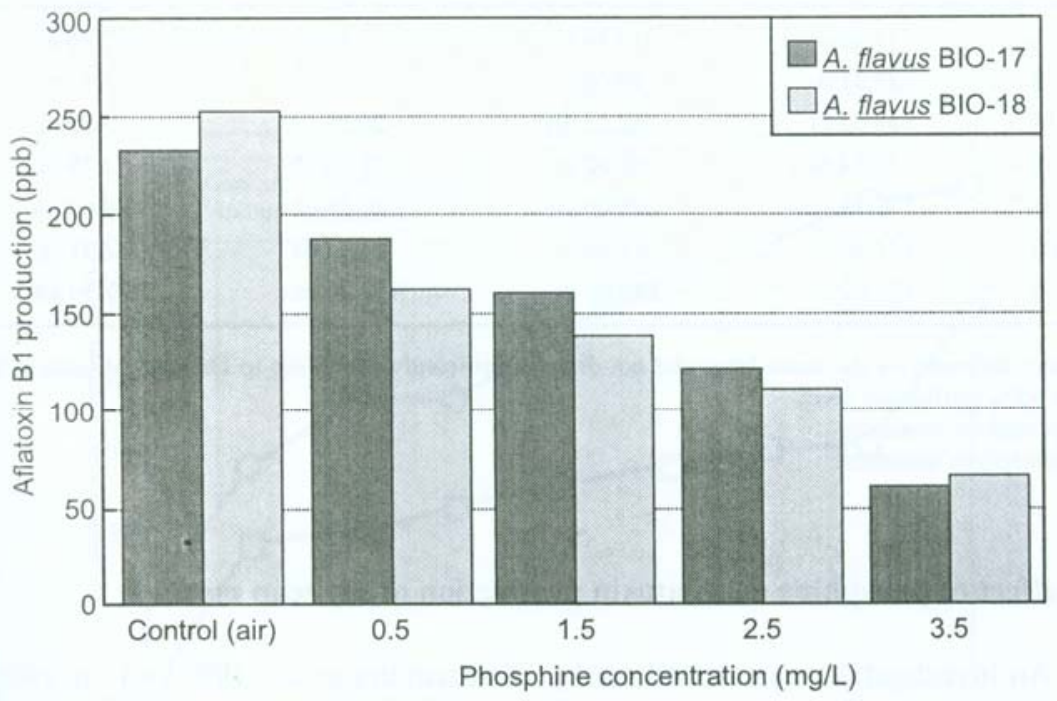

Figure 5. Aflatoxin $\mathrm{B}_{1}$ production of A. flavus $\mathrm{BIO}-17$ and $\mathrm{BIO}-18$ after treatment with different concentrations of phosphine for $5 \times 24 \mathrm{~h}$ on Coconut Extract medium 10\% (Dharmaputra et al. 1991). 


\section{The effectivity of phosphine to maintain the quality of maize packed in two different bag types}

Another study was conducted by Putri et al. (1999) on the effectivity of phosphine to maintain the quality of maize packed in two different bag types. Maize with initial moisture content of $\pm 14 \%$ was stored in two bag types, namely jute and polypropylene bags, and then laid on the wooden pallet for 130 days. Phosphine fumigation was carried out for 5 days at the beginning of storage and after 95 days of storage. Maize samples (treated with phosphine and untreated one) were taken just before and immediately after fumigation, and thereafter every 30 days for a period of 130 days. The results indicated that the highest total aflatoxin B, content was found in unfumigated jute bag, followed by unfumigated polypropylene bag, fumigated jute bag, and fumigated polypropylene bag (Tab'le 9).

\section{Table 9. Total aflatoxin $\mathrm{B}_{\mathrm{t}}$ content on maize in unfumigated and fumigated bags during storage (Putri
et al. 1999).}

\begin{tabular}{|c|c|c|c|c|}
\hline \multirow{3}{*}{$\begin{array}{c}\text { Storage } \\
\text { duration } \\
\text { (days) }\end{array}$} & \multicolumn{4}{|c|}{ Total aflatoxin $B_{1}$ content (ppb) } \\
\hline & \multicolumn{2}{|c|}{ Unfumigated } & \multicolumn{2}{|c|}{ Fumigated } \\
\hline & Jute bag & Polypropylene bag & Jute bag & Polypropylene bag \\
\hline $0^{\text {a) }}$ & $17.44 n$ & $17.49 \mathrm{n}$ & $17.40 \mathrm{n}$ & $17.49 \mathrm{n}$ \\
\hline 5 & $23.31 \mathrm{n}$ & $20.48 \mathrm{n}$ & $19.48 \mathrm{n}$ & $17.57 \mathrm{n}$ \\
\hline 35 & $48.92 \mathrm{kl}$ & $42,75 \mathrm{~lm}$ & $20.28 \mathrm{Im}$ & $35.22 \mathrm{~m}$ \\
\hline 65 & $70.14 \mathrm{hi}$ & $61.62 \mathrm{ij}$ & $58.43 \mathrm{ijk}$ & $52.78 \mathrm{jkl}$ \\
\hline $95^{b)}$ & $109.13 \mathrm{~cd}$ & $105.00 \mathrm{~cd}$ & $87.28 \mathrm{ef}^{-}$ & $74.62 \mathrm{gh}$ \\
\hline 100 & $121.80 \mathrm{~b}$ & $117.16 \mathrm{bc}$ & $97.42 \mathrm{de}$ & $82.91 \mathrm{fg}$ \\
\hline 130 & 149.62 a & $140.65 \mathrm{a}$ & $117.26 \mathrm{bc}$ & $107.59 \mathrm{~cd}$ \\
\hline
\end{tabular}

Numbers followed by the same letter did not differ significantly according to Duncan's Multiple Range Test at $95 \%$ confidence level.

a) $1^{\text {st }}$ phosphine treatment

b) $2^{\text {nd }}$ phosphine treatment

\section{The effect of phosphine on aflatoxin production of soybean meal}

An investigation was carried out by Dharmaputra et al. (1993) on the effect of phosphine on aflatoxin production of stored soybean meal. Soybean meal was stored in polypropylene bags for 190 days. Four stacks were treated with phosphine $(2.1 \mathrm{~g} / \mathrm{t})$ for 5 days, once at the beginning of storage and again after 95 days of storage. Four untreated stacks served as control. 
There was a significant difference in aflatoxin $\mathrm{B}$, content between the treated and the untreated samples (Table 10). Aflatoxin B, content increased during prolonged storage in both treated an untreated soybean meal (Figure 6). The results indicated that phosphine somehow inhibits aflatoxin BI production.

Table 10. Aflatoxin $\mathrm{B}_{1}$ content on soybean meal treated with phosphine and control (Dharmaputra $e t$ al. 1993).

\begin{tabular}{cccc}
\hline \multirow{2}{*}{$\begin{array}{c}\text { Storage duration } \\
\text { (days) }\end{array}$} & \multicolumn{2}{c}{ Aflatoxin $\mathrm{B}_{1}$ content $(\mathrm{ppb})$} & \multirow{2}{*}{ F-value } \\
\cline { 2 - 3 } & Control & Phosphine & \\
\hline $0^{\mathrm{a})}$ & 5.82 & 0.00 & \\
5 & 14.49 & 9.42 & 0.46 \\
35 & 18.35 & 9.92 & $14.77^{*)}$ \\
65 & 18.42 & 11.21 & $23.50^{* *)}$ \\
$95^{\text {b) }}$ & 22.42 & 12.67 & $10,255.91^{* *)}$ \\
$100^{*}$ & 24.94 & 14.06 & $\left.32,828.57^{* *}\right)$ \\
130 & 27.85 & 14.84 & $497.96^{* *)}$ \\
160 & 30.25 & 15.28 & $1,625.72^{* *)}$ \\
190 & 31.12 & 23.55 & $10.33^{*)}$ \\
\hline
\end{tabular}

a) $1^{\text {st }}$ phosphine treatment

b) $2^{\text {nd }}$ phosphine treatment

*) Significant difference at $95 \%$ confidence level

**) Significant difference at $99 \%$ confidence level

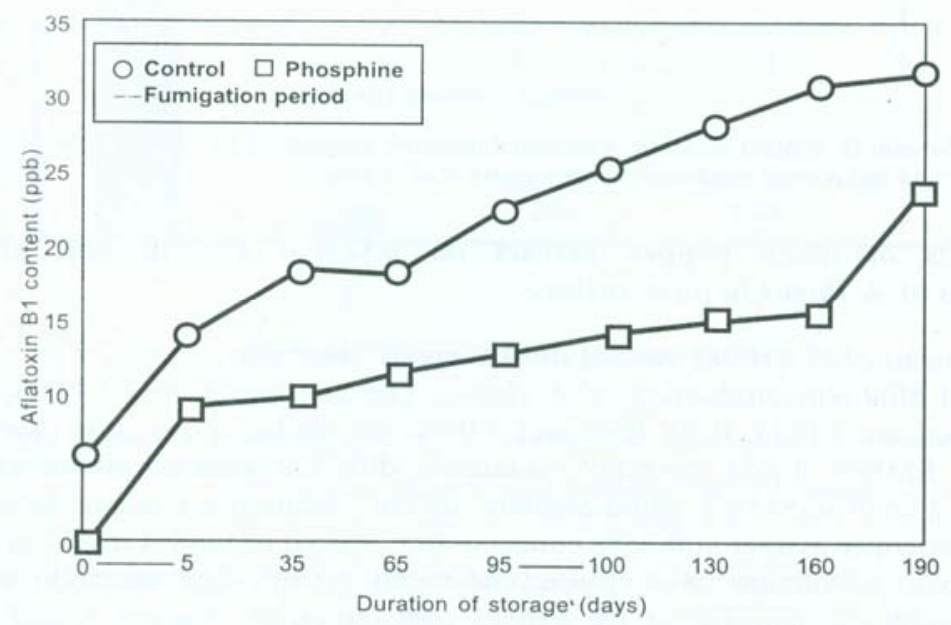

Figure 6. Aflatoxin $\mathrm{B}_{1}$ content on soybean meal treated with phosphine and control (Dharmaputra et al. 1993). 


\section{The effect of airtight storage on aflatoxin production in maize}

An investigation was carried out by Dharmaputra et al. (2000) on the effect of airtight storage on aflatoxin production in maize. The maize was placed in polyethylene bag under airtight condition (initial $\mathrm{O}_{2}$ content was $1.4 \pm 0.1 \%$ ), and stored for six months under laboratory conditions. The initial moisture contents of maize were $14 \pm 0.3,17 \pm 0.2$ and $20 \pm$ $0.2 \%$. As control, maize with the same initial moisture contents was placed in polyethylene bag under normal condition (air) with $\mathrm{O}_{2}$ content of $21 \%$.

The total aflatoxin $\mathrm{B}$, content on maize with the three initial moisture contents packed under normal condition was higher than under airtight condition (Figure 7). The total aflatoxin B! content increased with the increase of storage duration.

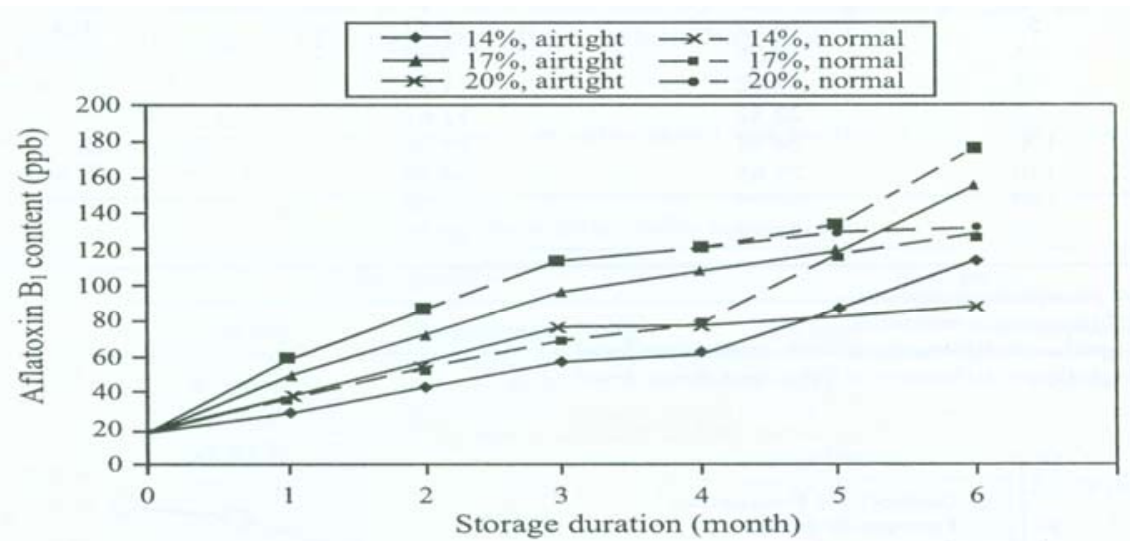

Figure 7. Aflatoxin $B_{1}$ content on maize with initial moisture contents of 14,17 and $20 \%$, stored under airtight and normal conditions (Dharmaputra et al. 2000).

The effects of black pepper extract on mycelial growth and aflatoxin production of A. flavus in pure culture

Retnowati et al. (1998) studied the effects of black pepper extract on mycelial growth and aflatoxin production of $A$. flavus. The concentrations of black pepper extracts used were 0.25 , $0.50,0.75$ and $1.00 \% \mathrm{v} / \mathrm{v}$ media. Aspergillus flavus was grown on SMKY liquid medium containing different concentrations of black pepper. As a control, SMKY liquid medium did not contain black pepper extract.

Black pepper extract at $0.25 \%$ concentration started to inhibit mycelial growth and aflatoxin production of $A$. flavus. Mycelial growth and aflatoxin contents decreased with the increase of the extract concentrations (Figures 8 and 9). No aflatoxin was detected on SMKY liquid medium containing $1 \%$ black pepper extract. 


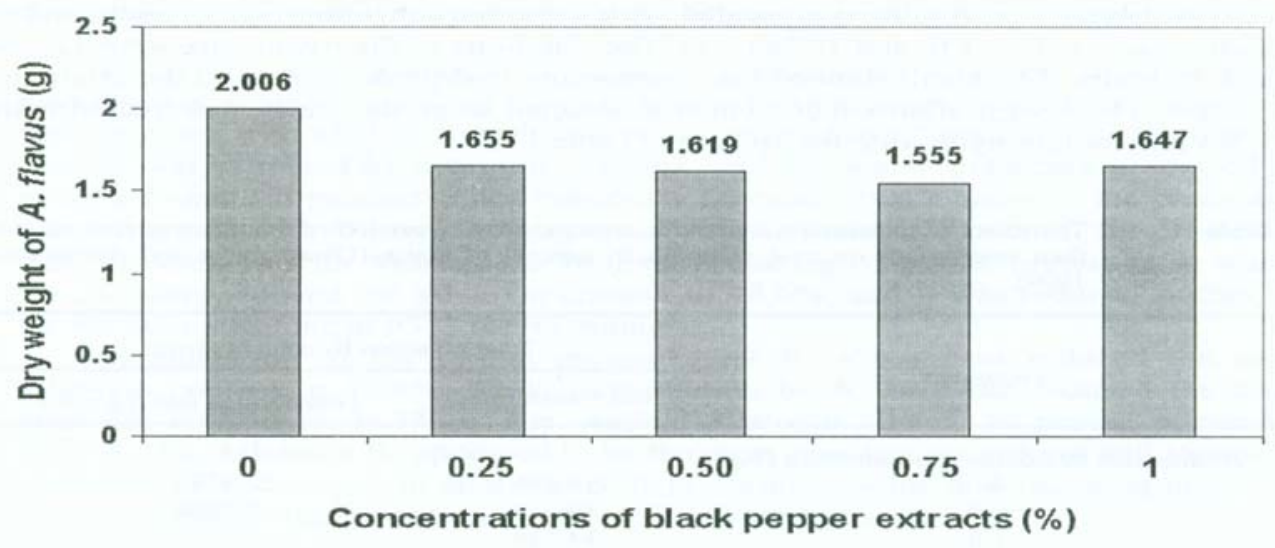

Figure 8. Dry weight of $A$. flavus on SMKY liquid medium containing different concentrations of black pepper extracts (Retnowati et al. 1998).

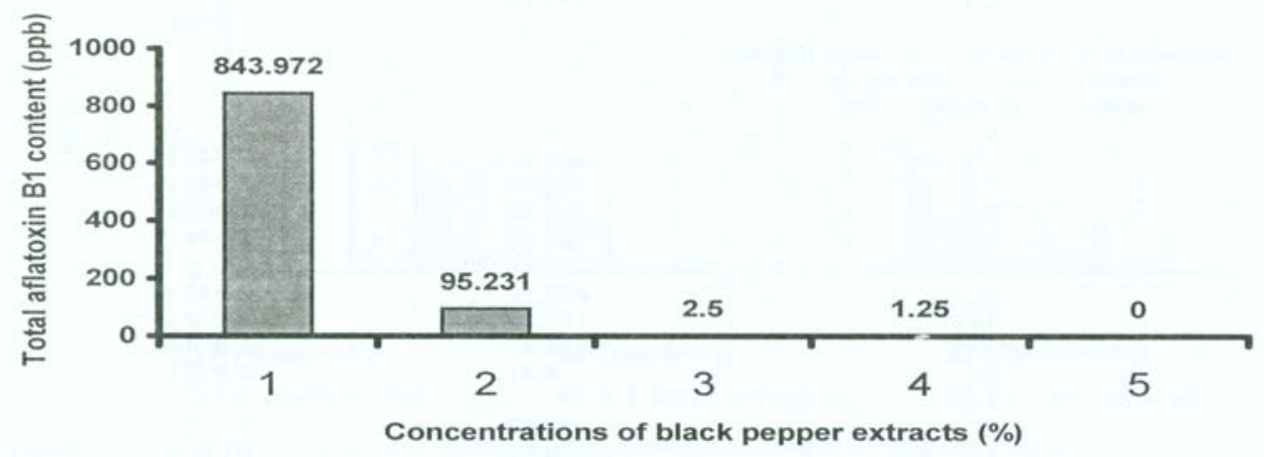

Figure 9. Total aflatoxin $\mathrm{B}_{1}$ content produced by A. flavus on SMKY liquid medium containing different concentration of black pepper extracts (Retnowati et al. 1998).

\section{The effect of ammonium hydroxide on aflatoxin production of maize}

The effect of ammonium hydroxide on aflatoxin production of maize stored under laboratory conditions was investigated by Dharmaputra and Ambarwati 
(1999). Maize var. Arjuna was treated with different concentrations of ammonium hydroxide, i.e. $0.5,1.0$, and $1.5 \%(\mathrm{v} / \mathrm{v})$. The durations of the treatments were 12, 24 and 36 hours. The result showed that ammonium hydroxide decreased the aflatoxin content. The lowest aflatoxin content was detected when the maize was treated with $1.5 \%$ ammonium hydroxide for 36 hours (Table 11).

Table 11. The effect of ammonium hydroxide concentrations, duration of ammonia treatment, and their interactions on total aflatoxin $B_{1}$ content of maize (Dharmaputra and Ambarwati 1999).

\begin{tabular}{|c|c|c|}
\hline \multirow{2}{*}{ Treatment } & \multicolumn{2}{|c|}{ Total aflatoxin $\mathrm{B}_{1}$ content (ppb) } \\
\hline & Not transformed & Transformed into $\log x+1$ \\
\hline \multicolumn{3}{|c|}{ Ammonium hydroxide concentrations (\%) } \\
\hline 0 & 218.070 & $2.338 \mathrm{a}$ \\
\hline 0.5 & 89.113 & $1.599 \mathrm{~b}$ \\
\hline 1.0 & 84.548 & $1.537 \mathrm{c}$ \\
\hline 1.5 & 73.013 & $1.349 \mathrm{~d}$ \\
\hline \multicolumn{3}{|c|}{ Duration of ammonia treatment (hours) } \\
\hline 0 & 220.895 & $3.342 \mathrm{e}$ \\
\hline 12 & 124.778 & $2.051 \mathrm{f}$ \\
\hline 24 & 59.628 & $1.296 \mathrm{~g}$ \\
\hline 36 & 59.445 & $1.136 \mathrm{~h}$ \\
\hline \multicolumn{3}{|c|}{$\begin{array}{c}\text { Interaction between ammonium hydroxide } \\
\text { concentrations }(\%) \text { and duration of } \\
\text { ammonia treatment (hours) } \\
0\end{array}$} \\
\hline 0 & 220.95 & $2.342 \mathrm{i}$ \\
\hline 12 & 220.89 & $2.344 \mathrm{i}$ \\
\hline 24 & 209.57 & $2.322 \mathrm{i}$ \\
\hline 36 & 220.88 & $2.344 \mathrm{i}$ \\
\hline \multicolumn{3}{|l|}{0.5} \\
\hline 0 & 220.90 & $2.342 \mathrm{i}$ \\
\hline 12 & 115.27 & $2.062 \mathrm{j}$ \\
\hline 24 & 11.87 & $1.074 \mathrm{~m}$ \\
\hline 36 & 8.41 & 0.9220 \\
\hline \multicolumn{3}{|l|}{1.0} \\
\hline 0 & 220.88 & $2.342 \mathrm{i}$ \\
\hline 12 & 100.74 & $2.003 \mathrm{k}$ \\
\hline 24 & 10.49 & $1.021 \mathrm{n}$ \\
\hline 36 & 6.08 & 0.784 o \\
\hline \multicolumn{3}{|l|}{1.5} \\
\hline 0 & 220.85 & $2.342 \mathrm{i}$ \\
\hline 12 & 62.21 & $1.794 \mathrm{j}$ \\
\hline 24 & 5.85 & $0.767 \mathrm{o}$ \\
\hline 36 & 3.14 & $0.496 p$ \\
\hline
\end{tabular}

Numbers followed by the same letter do not differ significantly according to Duncan's Multiple Range Test at $95 \%$ confidence level. 


\section{The effect of fermentation process on the aflatoxin production of peanuts}

The effect of traditional fermentation process on aflatoxin production of peanuts was studied by Edi et al. (1990) and Fardiaz et al. (1993). Peanuts were contaminated with aflatoxin-producing $A$. flaws, and incubated at $30^{\circ} \mathrm{C}$ for 6 days. The oil was extracted by hydraulic pressure, and the peanut presscake processed to make a fermented product called "oncom". To make "bla'ck oncom", the presscake was fermented with Rhizopus oligosporus, while to make "red oncom" the presscake was fermentated with Nenrospora sitophila. Soaking of peanut presscake in water for 24 hours reduced the aflatoxin content to $48.6 \%$, and it was reduced further to $42.9 \%$ after steaming at $95^{\circ} \mathrm{C}$ for 90 minutes.

Fermentation of the peanut presscake by $R$. oligosporus reduced the total aflatoxin content to $13.4 \%$, while fermentation by $N$. sitophila reduced the total aflatoxin content to $41.1 \%$ of the original aflatoxin content in peanut presscake (Figure 10). Aflatoxin B, appeared to be the most sensitive to soaking and steaming processes. The decrease in aflatoxin content during soaking and steaming might be due to leaching, since aflatoxin is relatively resistant to heat.

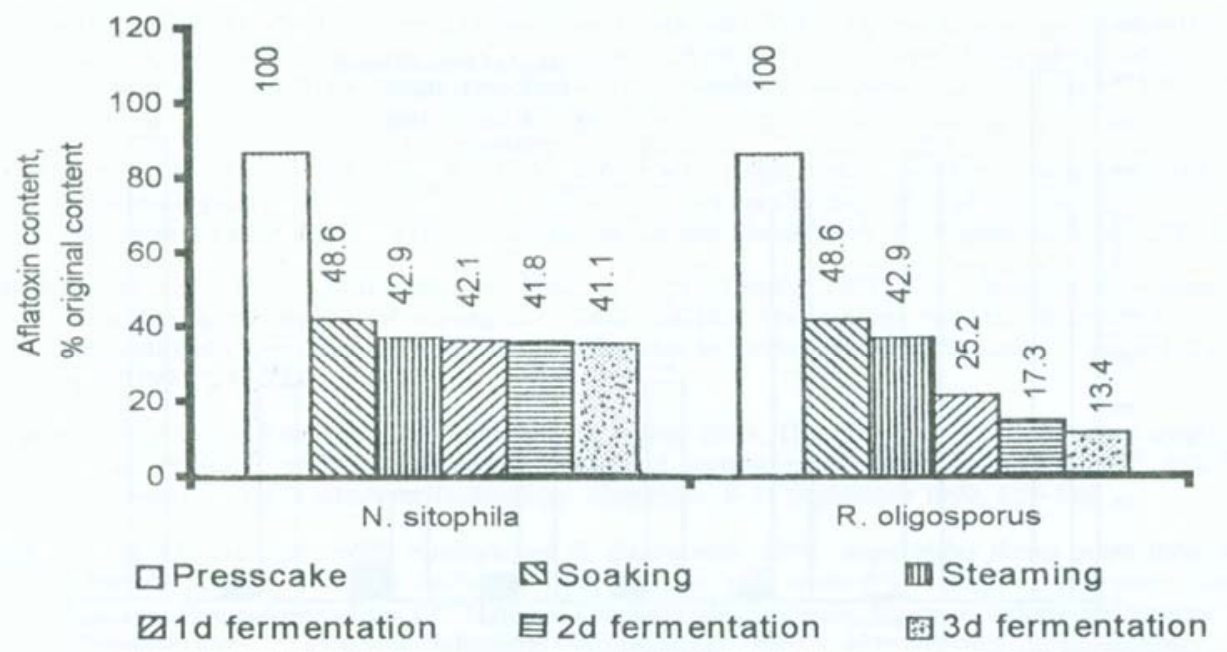

Figure 10. The effect of fermentation process on aflatoxin content of peanuts (Edi et al. 1990; Fardiaz et al. 1993).

\section{The effect of bag types on aflatoxin production of peanuts}

Bulaong and Dharmaputra (2002) studied the effect of four bag types namely jute bag, poly-propylene bag, jute bag lined with thin polyethylene (PE), and jute bag lined with thick $\mathrm{PE}$, on aflatoxin production of peanuts with initial moisture content of $8 \%$. Storage was done for 6 months under warehouse conditions. 
No significant differences were obtained in aflatoxin levels among bag types, but at the end of six months storage, aflatoxin contents of peanuts packed in jute bag, polypropylene bag, jute bag lined with thin PE, and jute bag lined with thick PE were 31.5, 23.1, 16.8 and 18.9 ppb, respectively. Based on the results, the immediate packaging of dried shelled peanuts at safe moisture level in jute bag lined with thin PE is recommended. The water vapor transmission rate of the thin PE is $1 \mathrm{~g} / \mathrm{m}^{2} / 24 \mathrm{~h}$.

\section{The effect of antagonistic fungi on aflatoxin production ofA.flavus in vitro}

Investigation was carried out by Dharmaputra et al. (2001) on the effect of fungi isolated from soil of peanut fields at Wonogiri regency, Central Java, on aflatoxin production of $A$. flavus. Figure 11 shows that $A$. niger was the most promising fungal antagonist, because it caused the highest percent inhibition (80\%) of aflatoxin production of $A$. flavus isolate $10_{2}$, followed by non-toxigenic $A$. flavus isolate $61_{2}(61 \%)$, A. tamarii (60\%) and non-toxigenic $A$. flavus isolate 36, (59\%).

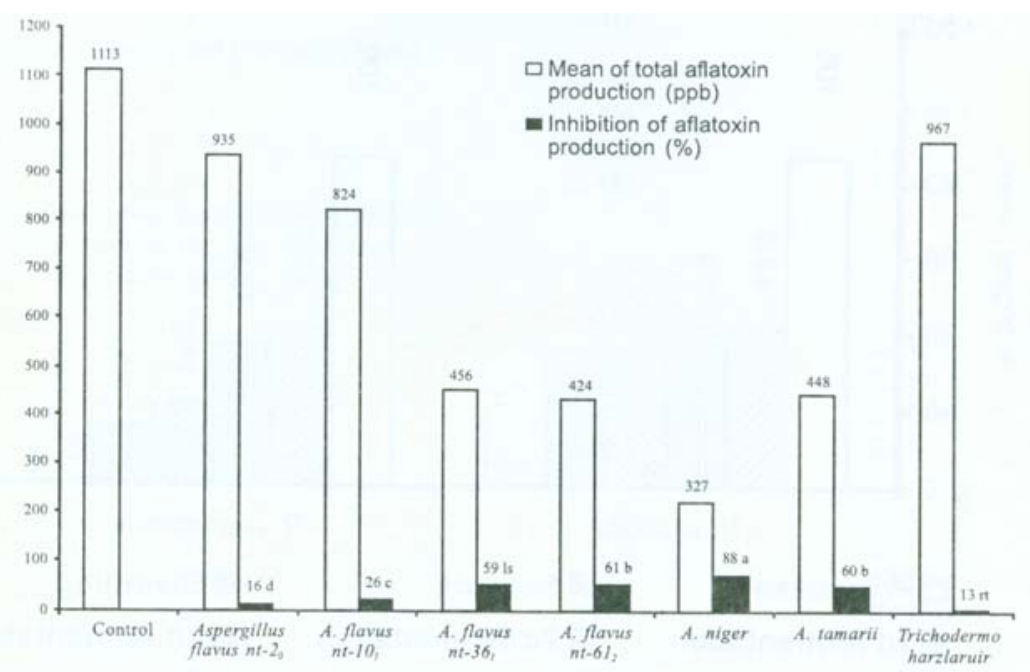

Figure 11. The effect of promising fungal antagonist on aflatoxin production of toxigenic A. flavus isolate $10_{2}$ and the percentage of inhibition (Dharmaputra et al. 2001).

\section{CONCLUSIONS}

Only very limited analyses and surveys on the extent of aflatoxin contamination in Indonesian food- and feedstuffs and their products have been carried out. High levels of aflatoxins were often found in maize and peanuts. Consequently, 
researches have been concentrated on the effects of postharvest handling and fumigation on fungal infection and aflatoxin production in those two commodities. In soybean meal, aflatoxin contents were relatively low.

No research has been carried out on aflatoxin contamination in relation with human health, cultural practices, peanut trading and industry. It is essential that a rigorous assessment of the critical points of entry of aflatoxin into the food and feed chains should be determined to more clearly assess the importance of pre-versus post-harvest management strategies.

\section{REFERENCES}

Bulaong, S.S.P. and O.S. Dharmaputra. 2002. Fungal population, aflatoxin and free fatty acid contents of peanuts packed in different bag types. BIOTROPIA No. 19: 1 - 25.

Dharmaputra, O.S., H.S.S. Tjitrosomo, F. Aryani and M. Sidik. 1990. The effect of carbondioxide on storage fungi of maize. Proceedings of the 5'" International Working Conference on Stored-product Protection, Bordeaux, France, 9-14 September 1990,291-301

Dharmaputra, O.S., H.S.S. Tjitrosomo, H. Susilo and Sulaswati. 1991. Aspergillusflavus and aflatoxin of peanuts collected from three markets in Bogor, West Java, Indonesia. Proceedings of the 12'" Asean Seminar on Grain Postharvest Technology, Surabaya, Indonesia, 29-31 August 1989, 110-123.

Dnarmaputra, O.S., H.S.S. Tjitrosomo, T.S. Wardani and H. Halid. 1992. The effect of carbondioxide on some biological aspects of Aspergillus flavus. Proceedings of the 13"' ASEAN Seminar on Grain Postharvest Technology, Bandar Seri Begawan, Brunei Darussalam, 4-7 September 1990, 280-293

Dharmaputra, O.S., H.S.S. Tjitrosomo, M. Sidik and R.C. Umaly. 1991. The effects of phosphine on some biological aspects of Aspergillus flavus. ACIAR Proceedings No. 36. Proceedings of an International Conference on Fungi and Mycotoxins in Stored products, Bangkok, Thailand, 23-26 April 1991,244-248

Dharmaputra, O.S., I. Retnowati, M. Sidik and H. Halid. 1993. The effects of phosphine and length of storage on fungi, aflatoxin and protein content of soybean meal. Proceedings of the $15^{11}$ ASEAN Seminar on Grain Postharvest Technology, Singapore, 8-11 September 1992, 125-136

Dharmaputra, O.S., I. Retnowati, Sunjaya and S. Ambarwati. 1995. Aspergillus flavus population and aflatoxin content in maize collected from farmers and traders in Lampung province, South Sumatra. Proceedings of the 12"' National Congress and Scientific Seminar, Indonesian Society for Phytopathology, Yogyakarta, Indonesia, 6-8 September 1993. Vol. 1, 560-566. (In Indonesian).

Dharmaputra, O.S., I. Retnowati, H.K. Purwadaria and M. Sidik. 1996a. Surveys on postharvest handling, Aspergillus flavus infection and aflatoxin contamination of maize collected from farmers and traders. Paper presented at the 17"' ASEAN Technical Seminar on Grain Postharvest Technology, Lumut, Perak, Malaysia, 25-27 July 1995. ACIAR Technical Reports 37, 38-53.

Dharmaputra, O.S., and A.S.R. Putri. 1996b. Aspergillus flavus population and aflatoxin content in maize, maize products and chicken feed. Paper presented at the National Microbiology Seminar and Annual Scientific Meeting, Malang, Indonesia, 12-13 November 1996. (In Indonesian).

Dharmaputra, O.S., H. Susilo and M. Sidik. 1997. Population of storage fungi and aflatoxin content of soybean meal. Proceedings of the 14"' National Congress and Scientific Seminar, Indonesian Society for Phytopathology, Palembang, Indonesia, Vol. 2,241-249. (In Indonesian). 
Review on Aflatoxin in Indonesia Food-and Feedstuffs and Their Products - Okky S. Dliarmaputrn

Dharmaputra, O.S., A.S.R. Putri and W. Setiawati. 1999. Fungal infection and possibility of aflatoxin contamination in black and white pepper. Hayati 6(3): 70-73. (In Indonesian with abstract in English).

Dharmaputra, O.S. and S. Ambarwati. 1999. Detoxification effects of ammonium hydroxide on aflatoxin and total nitrogen content of maize. Hayati 6(2): 25-28

Dharmaputra, O.S., 1. Retnowati, M. Amad and S. Ambarwati. 2000. Airtight storage of maize: its effect on fungal infection and aflatoxin production. Proceedings of the $19^{\prime \prime}$ ASEAN and $1^{\text {st }}$ APEC Seminar on Postharvest Technology, Ho Chi Minh City, Vietnam, 9-12 November 1999, 474-482

Dharmaputra, O.S., A.S.R. Putri, I. Retnowati and S. Ambarwati. 2001. Antagonistic effect of soil mycobiota on aflatoxin-forming Aspergillus flavus in vitro. Paper presented at the 20"' ASEAN and 2"d APEC Seminar on Postharvest Technology. Chiang Mai, Thailand, 11-14 September 2001.

Dharmaputra, O.S., A.S.R. Putri and Lilieanny. 2002. Population of storage fungi and aflatoxin content in peanut products. Internal Report. SEAMEO BIOTROP. (In preparation).

Edi, S. Fardiaz and D. Fardiaz. 1990. Production of aflatoxin by Aspergillus flavus and its destruction during fermentation of peanuts by Neurospora sitophila. Buletin Penelitian Ilmu dan Teknologi Pangan 1(1): 18-31. (In Indonesian).

Fardiaz, S., S. Wulan and B. Setiyadi. 1993. Effect of fermentation by Rhizopus oligospoms on aflatoxin production by Aspergillus flavus in peanut presscake. Proceedings of the $5^{1_{1}{ }_{1}}$ ASEAN Food Conference, akarta, Indonesia, February 1992, 858-864

Haryadi, Y. and E. Setiastuty. 1994. Characterisation of aflatoxins $\mathrm{Bi}, \mathrm{B}_{2}$, d and $\mathrm{G}_{2}$ in groundnuts and groundnut products. Proceeding of the 6"' International Working Conference on Stored-product Protection, Canberra, Australia, Vol. 2, 996-998.

Maryam, R. 1994. Kontaminasi asam siklopiazonat dan aflatoksin pada jagung. Makalah dibawakan pada Kongres Nasional Perhimpunan Mikologi Kedokteran Manusia dan Hewan Indonesia I dan Tcmu Ilmiah. Bogor, 21-24 Juli 1994, 289-293

Pitt, J.I. and A.D. Hocking. 1996. Current knowledge of fungi and hiycotoxins associated with food commodities in Southeast Asia. Mycotoxin Contamination in Grains. ACIAR Technical Reports 37, 5-10

Purwoko, H.M., B. Hald and J. Wolstrup. 1991. Aflatoxin content and number of fungi in poultry feedstuff's from Indonesia. Letters in Applied Microbiology 12: 212-215

Putri, A.S.R., O.S. Dharmaputra, Sunjaya and M. Sidik. 1999. The effectiveness of phosphine to maintain the quality of maize packed in two different bag types. Proceedings of the $7^{1_{1}^{\prime}}$ International Working Conference on StoredProduct Protection, Beijing, P.R. China, 14-19 October 1998, 274-279

Retnowati, I., O.S. Dharmaputra, H. Susilo and H. Affandi. 1998. Inhibitory effects of black pepper and turmeric extracts onf the growth and aflatoxin production of Aspergillus flavus. Proceeding of the National Microbiology Seminar and Annual Scientific Meeting, Bandar Lampung, Indonesia, 14-15 December 1998, 210-220. (In Indonesian with abstract in English)

Ventikitasubramanian, T.A. 1977. Biosynthesis of aflatoxin and its control. In Rodricks, J.V., C.W. Hesseltine and M.A. Mehlman (eds.). Mycotoxin in Human and Animal Health. Pathotox Publishers Inc., part Forest South, Illinois, 83-98

Zahari, P. and Tarmudji. 1995, Aflatoksikosis pada ternak itik Alabio di Kalimantan Selatan. Presiding Seminar Nasional Teknologi Veteriner untuk Meningkatkan Kesehatan Hewan dan Pengamanan Bahan Pangan Asal Ternak. Cisarua, Bogor, Indonesia, 22-24 Maret 1994, 408-41 1 